\title{
Color Palette of Emily Dickinson Worldview: Linguistic and Literary Approach
}

\author{
Mosolkova M.G. ${ }^{\mathrm{a}}$ \\ Mardanshina R.M.b \\ Kalganova G.F.c
}

a b c Kazan Federal University, Institute of Management, Economics and Finance, Kazan, 420008, Russia

Email: Marina.Mosolkova@mail.ru

\section{Doi:10.5901/mjss.2015.v6n1s3p331}

\section{Abstract}

The main purpose of this article is to reveal the semantic functions of different colors in Emily Dickinson's creation. Linguistic and literary studies approach is used to conduct a parallel study of writer's worldview coloring both in poetry and in letters. It comprises a set of theoretical statements, the ranking of preferable colors in Dickinson's creation. Color description is linked to the traditions of semantic and stylistic analysis of a literary text.

Keywords: poem, letter, world perception, color palette, image creation, semantic function, integrated approach.

\section{Introduction}

It is generally known, that people use three primary representational systems - visual, auditory and kinesthetic (referred to as VAK learning styles) - to experience the world. However, depending on a person and the context, they may choose the one most appropriate and preferred representational system. When learning something new and depicting it, some people may prefer to see it or to imagine it, others need to get a feeling for it or just to hear how to do it.

In general, a whole range of interrelated emotional and associative additions (colour, light, sound, space, distance etc.) contributes to the perception of the world.

Following the analysis of Emily Dickinson creativity, we concluded that she focuses mainly on visual style. Therefore, in this article we refer to color as one of the primary elements of her artistic system and its specific stylistic function in the formation of an image. Emily Dickinson color palette is varied, and color adjectives are used literally and figuratively.

It is recognized by many scientists that Emily Dickinson is a writer of unique power and quality (Dobson J., Longsworth P., Monteiro G., Pollak V., Salter M.J. Urbanowich M.). Some scientists refer to the theme of color designation in Dickinson's poetry. G. Johnson mentions her sense of color [Johnson, 1985]. N. Tandon and A. Trevedi note that "she was fascinated by the phenomena of nature, by the variety of its color and sound and with her characteristic analytical mind, she explored the complex implications of her experience" [Tandon, 2008].

We conducted a parallel study of Emily Dickinson coloring both in poetry and in letters integrating linguistic and literary analysis.

\section{Scope of Research}

The proposed research has both linguistics and literary studies focus. 1764 poems and 1047 letters written by Emily Dickinson in different periods of her life serve as the research object. Taking into account the scope of our research, we intended to identify:

- changes in author's priorities of color selection;

- changes in the emotional and mental state;

- permanent and non-permanent features of the author's literary texts content organization depending on the period of time when literary works were created. 


\section{Theoretical Background}

Words for colors form a separate lexico-semantic group. Group constituents, their semantics and correlation are historically volatile, and it is determined by the variability of consciously chosen extra linguistic reality.

The semantic development of color words resulted in coexistence of direct, figurative and symbolic meanings of the words at different stages of language development including modern language. This interrelation of meanings is actively used in different kinds and genres of artistic creation.

Individual color designation connotations of different authors are usually based on objective properties of the lexical system elements implemented in the language or on potential properties of words for colors. Although a writer uses common language meanings and relations of the words, while creating his vision of the world he rethinks these meanings and thereby promotes both further development of intersystem relations within the semantic group and the inclusion of these elements in the interaction with other lexico-semantic groups.

Color characteristics due to their semantic and emotional intensity serve as a medium of translating the aesthetic ideals of the author. They represent his assessment and his attitude towards the world he describes, provide the disclosure of writer's ideas and views. In other words, color characteristics reflect author's perception of the world.

Color perception in a literary text has its own specificity that differs substantially from the immediate visual sensations inherent to everyday human activities. The importance of color in the formation of the ideas of beauty is generally known. From the outset of human civilization the emotional effect of color enhanced the feeling of joy of life. As an element of a poetic atmosphere of narration, it always participates on a par with others in the creation of an artistic image.

It should be noted that the research of figurative and poetic function of color words in fiction aimed at identifying the author's individual features of using color designations is of a particular interest.

Monographic works of Russian scientists R.V. Alimpieva, S.V. Bekova, L.A. Kachaeva, L.V. Zubova are justifiably considered to be the starting point in the research of symbolic and emotional functions of color words in fiction. Their research shows that color terms can serve as a visual means; they provide tools to identify the subtext, and express characters' thoughts and feelings. Color lexicon builds their perception of the world and contributes to special emotional spirit of a literary text.

In this way, color adjective gains a new aesthetic content in a literary text, which implies the emergence of a new aesthetic meaning. It turns to a special philological and aesthetic unit capable of complementing author's individual style, and thus showing the coloring of his creation and even the coloring of the literary movement.

Therefore, the research of color description in Emily Dickinson letters and poetry can be organically linked to the traditions of semantic and stylistic analysis of a literary text.

\section{Semantic and Stylistic Analysis}

We examined Emily Dickinson's letters and poetry written between 1842 and 1886. The statistical analysis of color usage in Emily Dickinson creation is revealed in Table 1 in descending manner.

Table 1. Color usage in Emily Dickinson letters and poetry (1842-1886)

\begin{tabular}{|c|c|c|}
\hline Rank & Color terms in letters & Color terms in poetry \\
\hline 1 & gold, golden & gold, golden, gilded \\
\hline 2 & blue & red (ruddy, blood, bleeding, scarlet, crimson, brick) \\
\hline \multirow{2}{*}{3} & green (evergreen, emerald); & purple \\
\cline { 2 - 2 } & red (blood, bloody, scarlet, ruddy, reddish) & white \\
\hline 4 & white & yellow (orange, amber, brass) \\
\hline 5 & brown & blue (indigo, lilac, violet) \\
\hline 6 & pink (rosy, rose-colored) & green (evergreen, emerald) \\
\hline 7 & black & silver \\
\hline 8 & silver & brown (umber, hazel) \\
\hline 9 & purple & pink \\
\hline 10 & yellow (fawn colored, gamboges) & grey \\
\hline 11 & grey & black \\
\hline 12 & & \\
\hline
\end{tabular}


Thus, the most widely used colors in poetry and letters are gold, red, purple, blue, green and white. Yellow is frequent in poems, but not in letters. Dickinson refers to these colors, because they are often found in nature. She borrows colors from the very nature. Nature for her is an artist who paints the world. Natural and artistic beginnings merge.

Both in poetry and in epistolary works the poet reflects on colors and natural color palette.

In her letter to Mrs. Holland (August 1876), she asks, "how nature would look in other than standard colors". Due to the drought "the grass is painted brown", and this unusual color attracts her attention.

Addressing to Samuel Bowls after Christmas 1869, she designates green and gold as immortal, unfading, eternal colors.

In the letter to the dear friend (no date), Dickinson thinks about her favorite colors, "perhaps I love the azure and gold myself". However, then she concludes, "perhaps we should learn to love and cultivate these ruddy hues of life", as in the poem to Mrs. Julia Howe, "I take my life upon the red".

If we consider in depth the use of the white color, owing to the wealth of figurative and symbolic meanings, it is widely used in the literature. Color adjective "white" is capable of transmitting conflicting human ideas about life and death.

This is confirmed in different religions and literature. In religion, it is the symbol of innocence, purity, holiness, chastity.

In accordance with the author's world perception, all semantic nuances of the adjective "white" - nominative, metaphorical and symbolic - are reflected in the poetry and epistolary heritage of Emily Dickinson in historical, philosophical and psychological contexts.

Specificity of Dickinson's relation to nature is largely due to the influence of transcendentalism. Transcendentalists deified nature, gave it a spiritual force, wrote about melding with nature, which was necessary and beneficial for the development of a personality.

The poet uses a rich palette of natural colors. She takes the whiteness of snow. The phrase "white as snow" is used in the description of objects, concepts, things that are not related with snow - "a little shell of a snail, so whitened by the snow". In this case, it is a snail shell, the color of which is compared with white snow.

\section{"A little snow was here and there \\ Disseminated in her Hair - \\ Since she and I had met and played \\ Decade had gathered to Decade".}

"Snow in hair" means gray hair. Emily Dickinson describes a meeting with her friends whom she did not see many years, replacing an epithet "white" with the description of the natural phenomenon. person):

Considering a person as a part of nature, Dickinson puts him in a dress from the purest snow (it is about the worthy

"Why, I have lost, the people know

Who dressed on frocks of purest snow".

She emphasizes a spiritual unification of the person with the nature. Moreover, personification is used when describing nature. She dresses the hills in clothes that are worn by the person. Nature, thus, is represented spiritualized, "Hills take off their purple frocks, and dress in long white nightgowns". The adjective of "white" gets metaphorical sense, the description of snow is introduced as an image of "a white shirt". The nature is animated, and season change assimilates to change of clothes.

Color "white" is often used in combination with nouns designating articles of clothing in direct and figurative meanings. On the one hand, we meet a traditional combination "white" with articles of clothing: "white hat", "white dress", "white frock". On the other hand, we know that Emily Dickinson was "a woman in white", and it becomes her image. In 1851 Dickinson visited the concert of Jenny Lind, a coloratura soprano from Sweden (the evidence is the letter to her brother Austen, June 22, 1851). Jenny was dressed in a white dress. Since 1851 Emily Dickinson began to give preference to white color, including clothes. Thus, white color probably becomes the symbol of art and selectness for the poet. In this case, "white" is projected on person's state. White clothes are the symbol of an artistic gift; the metaphor of "white wings" is the symbol of inspiration. In the context of letters and poems "white" becomes the synonym of "saint" and acquires one more figurative meaning. The phrase "white hands" is used in the meaning of "pure", "innocent", "chaste", "sacred hands".

Emily Dickinson often uses an adjective "white" both both in poetry and letters in the meaning of "joyful", "light" connecting it with the image of the house colored by the nature: 
"... my House, which Nature painted White".

"White House the Earth".

It should be noted that Dickinson uses the white color describing a disease state of a person. The word "white" gets a semantic shade of fragility reminding the comparison with a short-lived moth.

The adjective "white" gets philosophical sense in relation to the death in one of her poems written in 1861, "the dead shall go in white".

The similar idea is repeated in the letter to an unknown addressee of the same year, "... - We can take the chances for Heaven - what would you do with me if I came in white". In the poem written in 1863 the adjective "white" is used twice, "white - unto the White Creator".

Thus, the death in Emily Dickinson's perception is associated not with gloom but with light. Bright perception of death is connected with transition to higher stage of existence. Both in poems and in letters "white" is sometimes replaced with the color of alabaster that, in turn, causes visual association with a cemetery.

The adjectives "blond" and "fair" can be referred to the semantic row of white color, and can be considered as contextual synonyms. "Blond" is used not only literally as the hair color (blond), but it also gains additional meaning of "light", "blessed", "blessing of god" - "God's little Blond Blessing". The same applies to the adjective "fair". The literal sense is blond for hair color and some figurative senses are "fair rotation" for season change, «fair expectation" pleasant expectation, "fair judgment"; for designation of shades is "fair Verdure".

\section{Conclusion}

White color in poetry and epistolary heritage of Emily Dickinson acquires the following generalized symbolic meanings: "poetic gift", "joyful, light", "granting the hope", "sacred, chosen", "white clothes", "white house", "white day", "white flowers".

The originality of Dickinson's art is her impressionistic "photographing" the subjective impressions and dividing them into smaller components. The storyteller is like "an apparatus" to capture and fix the impressions of the world perception, which turns to the perceiving person with its sensual side.

The main art functions of Emily Dickinson's color lexicon are:

- strengthening the verbal images expressiveness and their emotional impact on the reader;

- participation in the expressing the content idea and the emotional spirit of a poem, including author's estimates, views and feelings;

- creation of the author's poetic images.

\section{References}

Dobson J. Dickinson and the strategies of reticence: The woman writer in nineteenth century. America. Bloomington, Indianapolis: Ind. U.P., $1989-160$ p.

Johnson G. Emily Dickinson: Perception and the poet's guest. Univ. of Ala. Press, 1985. $231 \mathrm{p}$.

Longsworth P. The world of Emily Dickinson. New York: Norton, 1990. - $136 \mathrm{p}$.

Monteiro G. The ordinary poetry of Mary E. Wilkins and Emily Dickinson. Arlington, 2001 - pp. 252- 260

Mosolkova M.G. (Kostitsina M.G.) The World of Emily Dickinson's poetic personality (Poetry and epistolario). Dissertation of Cand. Phil. Sci. Kazan Univ. Press, 2004. 208 p.

Pollak V. Dickinson and the Poetics of Whiteness. - John Hopkins University Press, 2000. - pp. 84-95.

Tandon N., Trevedi A. Thematic Patterns of Emily Dickinson's Poetry. New Delhi: Atlantic Publishers and Distributors (p) Ltd., 2008. 173 p.

Salter M.J. Puns and accordions: Emily Dickinson and the unsaid. Yale rev. - New Heaven, 1990. - pp. 188-221.

Urbanowich M. Singing off the Charnel Steps: Soldiers and Mourners in Emily Dickinson's War Poetry. New York: John Hopkins University Press, 2000. - pp. 64-74. 